\title{
Improving Farmers' Efficiency in Rice Production In Nigeria: The Relevance of Agricultural Extension
}

\author{
Usman, S., Ilu, I. Y. and Sa'adatu B.A. \\ National Agricultural Extension Research and Liaison Services (NAERLS) ABU Zaria. \\ *Email Address:- sausmanshehu@yahoo.com GSM:- 08034569990
}

\begin{abstract}
This paper assesses the effects of extension services on farmers' efficiency and productivity in rice production in Kano State, Nigeria. Data for the study were collected from 126 rice farmers selected using multi stage sampling technique. Stochastic production frontier function was estimated to ascertain the effects of extension services on increasing efficiency and productivity in rice production. In addition to raising farmers' efficiency and increasing potential output, farmer access to extension services significantly $(p<0.01)$ reduces production inefficiencies and yield losses. It is recommended that farmers' accessibility to agricultural extension should be enhanced. Also, provision of effective extension services to farmers should be highly considered in the current agricultural transformation programmes.
\end{abstract}

Key words: Rice, efficiency, Extension, Kano State.

\section{Introduction}

Nigeria is one of the largest rice markets in Africa, with an estimated population of 167 million people, growing at 3.2\% annually and predicted to reach 221 million by 2020 (NPC, 2006). Nigeria's rice consumption has increased quite significantly over the last decade (6-7\% per annum) and is now estimated at 6 million metric tonnes annually. In both urban and rural areas, rice has become a staple food of choice accounting for more than $20 \%$ of all meals consumed per week by a typical household. Nigeria's growing demand for rice is the effect of shifts in consumer preferences driven by urbanization and changes in employment patterns. Rice consumption in Nigeria is forecasted to reach 36 million tonnes by 2050 (FMARD, 2012).

Although, Nigeria is endowed with abundant natural resources suitable for rice production to domestically produce more than enough rice and even export surplus, yet the demand outstrips domestic supply. Nigeria's growing rice demand simultaneously presents a food security challenge and an economic opportunity for the country. Currently, a third (2 million $\mathrm{mt}$ ) of Nigeria's rice demand is being met by importation, due to low adoption rate, low yield and inefficient production systems (FMARD, 2012). The average rice yield in the country is low and it ranges between 1000 and 2500kg/hectare (Amaza and Maurice, 2005; Ekeleme, et. al, 2008; Ayinde, et al., 2009). On the other hand, Ekeleme, et al. (2008) found that if farmers have access to effective demand - responsive extension services and efficiently allocate resources about $7600 \mathrm{~kg} / \mathrm{hectare}$ could be realised, given the current state of rice production technology.

Accordingly, the Federal Government of Nigeria, as part of its Agricultural Transformation Agenda (ATA), has set a goal to achieve complete self sufficiency in rice production in the next $3-4$ years. This implies achieving a significant increase in local production of rice to substitute about 2 million $\mathrm{mt}$ of rice currently being imported. To achieve this goal, agricultural extension services deserve a priority position in the current agricultural transformation agenda.

Evidently, extension services are expected to improve efficiency in all spheres of agricultural activities along the rice value chain activities. According to Daneji, et al., (2010) a positive return to agricultural extension services arises because extension 
system assists farmers to be better managers, adopt more modern farm inputs and prefer risky (high-return) production technologies.

Despite such common beliefs regarding the benefits of extension in farm activities, there is little empirical evidence on effects of extension services on farm-level efficiency in rice production to advocate public investment in Nigerian rice industry. Studies (Amaza and Maurice, 2005; Okoruwa and Ogundele, 2006; Ogundari and Ojo, 2007; Olarinde, et al., 2008; Ayinde, et al., 2009) on rice production efficiency in Nigeria focus on many determinants of efficiency without focusing on the role of extension activities in improving production efficiency.

In view of the perceived importance of extension services in raising farm productivity and efficiency in agriculture and existing knowledge gap, the study was aimed to assess effect of extension services on rice farmers' productivity and efficiency, that is, whether rice farmer's access to extension services is relevance to achieving self sufficiency in rice production through increased farm-level efficiency and significant reduction in yield losses.

\section{Methodology}

The study was carried out in Kano State, located in the Northern part of Nigeria between latitudes $13^{\circ} \mathrm{N}$ and $11^{\circ} \mathrm{S}$ and longitude $8^{\circ} \mathrm{W}$ and $10^{\circ} \mathrm{E}$. The state has a land mass of about 20760 square $\mathrm{km}$ (NAERLS, 2010). Based on NPC (2006), the state has a projected population of $11,206,688$ in 2012 . The average annual rainfall is $700 \mathrm{~mm}$ with the mean daily maximum and minimum temperatures of $35^{\circ} \mathrm{c}$ and $19^{\circ} \mathrm{c}$, respectively. The major crops grown in the State include rice, maize, millet, cowpea, groundnut and vegetables (NAERLS, 2010).

A multi stage random sampling technique was used to obtain a sample of 126 rice farmers. In the first stage, the three major rice producing LGAs (i.e. Kura, Garun Malam and Bunkure LGAs) were purposively selected out of 44 LGAs in the State. Secondly, a major and accessible rice producing village was purposively chosen from each LGA. Thirdly, $11 \%$ of the given sample frames of rice farmers in each chosen village were randomly selected. The third stage involved a simple random selection of 77 rice farmers that had access to extension visits and 49 rice farmers that did not have contact with extension agent in the production season. Thus a total of 126 farmers were used for the study (Table 1). 
Table 1. Proportion of rice farmers selected from villages' rice sample frames

\begin{tabular}{|c|c|c|c|c|c|}
\hline \multirow[b]{2}{*}{ LGAs } & \multirow[b]{2}{*}{$\begin{array}{l}\text { Villages } \\
\text { chosen }\end{array}$} & \multicolumn{2}{|c|}{ Rice farmers' Sample frames } & \multicolumn{2}{|c|}{$11 \%$ of the sample frame } \\
\hline & & $\begin{array}{l}\text { With } \\
\text { extension } \\
\text { contact }\end{array}$ & $\begin{array}{l}\text { Without } \\
\text { extension } \\
\text { contact }\end{array}$ & $\begin{array}{l}\text { With } \\
\text { extension } \\
\text { contact }\end{array}$ & $\begin{array}{l}\text { Without } \\
\text { extension } \\
\text { contact }\end{array}$ \\
\hline Kura & Dan Hassan & 217 & 109 & 24 & 12 \\
\hline $\begin{array}{l}\text { Garun } \\
\text { Malam }\end{array}$ & Garun Babba & 311 & 105 & 34 & 12 \\
\hline Bunkure & Lautaye & 168 & 224 & 19 & 25 \\
\hline Total & 3 & 696 & 438 & 77 & 49 \\
\hline
\end{tabular}

Source: Field survey, 2010

Data were collected based on the 2010 cropping season from the sampled farmers using a structured questionnaire and interview schedule. The information collected from the farmers includes rice production inputs and output, socio-economic, demographic and institutional characteristics of the farmers.

\section{Analytical framework}

Stochastic production frontier model also called 'composed error' model developed concurrently by Aigner et al., (1977) and Meeusen and van den Broeck, (1977) was adopted. The stochastic production frontier model is generally defined as:

$Y_{i}=f\left(X_{i} ; \beta\right)+\varepsilon_{i}$

where $Y_{i}$ is output of the ith farms, $X_{i}$ is a vector of inputs used by farm $i$, and $\varepsilon_{i}$ is a "composed" error term. The error term $\varepsilon_{i}$ is equal to $v_{i}-u_{i}$. The term $v_{i}$ is a two-sided $\left(-\infty<v_{i}<\infty\right)$ normally distributed random error $\left(v \sim N\left[0, \sigma_{v}^{2}\right]\right)$ that represents the stochastic effects outside the farmers' control. The term $u_{i}$ is a one-sided $\left(u_{i} \geq 0\right)$ efficiency component that represents the technical inefficiency of farm. The distribution of the term $u_{\tilde{i}}$ can be half-normal, exponential, or gamma (Aigner et al. 1977; Meeusen and van den Broeck, 1977) and half-normal distribution $\left(\mathrm{u} \sim N\left[0, \sigma_{u}^{2}\right]\right)$ is used in this study. The two components $v_{i}$ and $u_{i}$ are also assumed to be independent of each other.

Technical efficiency (TE) of an individual firm is defined in terms of the ratio of the observed output to the corresponding frontier output, conditioned on the level of inputs used by the firm. Technical inefficiency is therefore defined as the amount by which the level of production for the firm is less than the frontier output. This is shown in equation (2)

$$
T E_{i}=\frac{Y_{i}^{*}(\text { observed output })}{Y_{i}(\text { frontier output })}=\frac{f\left(X_{i} \beta\right) \exp \left(V_{i}-U_{i}\right)}{f\left(X_{i} \beta\right) \exp \left(V_{i}\right)}=\exp \left(-U_{i}\right)
$$




\section{Empirical model}

There are several functional forms for estimating the physical relationship between inputs and output but Cobb-Douglas functional form is preferable to other forms if there are three or more independent variables in the model (Hanley and Spash, 1993). Hence, Cobb-Douglas production function with four input independent variables was applied in this study. The four input independent variables were farm size in hectares, inorganic fertilizer in $\mathrm{kg}$, human labour in man-hours, and quantity of seed in kg while the dependent variable output is rice in $\mathrm{kg}$. The empirical Cobb-Douglas stochastic frontier model is specified as:

$\ln Y_{i}=\beta_{0}+\sum_{j=i}^{4} \beta_{i j} \ln X_{i j}+v_{i}-u_{i} \ldots \ldots \ldots \ldots \ldots$

In this study, the level of inefficiency in rice production is evaluated by the deviation from the frontier. Therefore, the effects of extension contact on efficiency are assessed by introducing farmer's access to extension visits as dummy variable in the 'inefficiency effects model' in addition to other variables representing farm and farmer characteristics to explain underlying causes of deviation from the frontier. The technical inefficiency effects $u_{\tilde{i}}$ is defined by

$u_{i}=\delta_{0}+\sum_{j=i}^{6} \delta_{i j} z_{i j} \ldots \ldots \ldots \ldots$

Where; $Z_{1}=$ is the age of the ith farmer, $Z_{2}=$ years of experience of the ith farmer in rice production, $Z_{3}=$ is a dummy variable, which has value one if ith farmer has access to extension agent and value zero for otherwise, $Z_{4}=$ years of schooling, $Z_{5}=$ amount of credit in Naira used, $Z_{6}=$ years of membership in farmers' cooperative, $\delta_{s}=$ are unknown scalar parameters. These were included in the model to indicate their possible impact on the technical efficiencies of the farmers.

The computer program FRONTIER 4.1 (Coelli, 1996) was used to obtain the maximum likelihood estimates of the $\beta_{s}$ and $\delta_{s}$ coefficients in equations (3) and (4), respectively.

\section{Results and Discussion}

\section{Socio-economic characteristics of the sampled farmers}

A summary of statistics of the variables used in the analysis is presented in Table 1. The mean and standard deviation of the values of the variables were computed for farmers that have extension contacts and those that have no extension contacts separately. The average farm sizes were 3.5 and 3.2 hectares for rice farmers with and without extension contacts respectively, implying that rice production was mainly done by small-scale farmers with average farm holding of less than 4 hectares. Mean rice yield of the farmers with extension contact was $2105.67 \mathrm{~kg} / \mathrm{ha}$ which are more than that of those rice farmers without extension contact with $1668.39 \mathrm{~kg} / \mathrm{ha}$, implying a relative decrease of over $26 \%$. Farmers with extension contact obtained higher yield by using more production inputs like fertilizers and seeds and less of human labour input. Similarly, the means of years of schooling and years of membership in farmers' cooperatives were 12 and 16 
years respectively for farmers with extension contact may probably influence attendance to extension services.

Table 2. Descriptive Statistics of the Variables used in the analysis

\begin{tabular}{|c|c|c|c|c|}
\hline \multirow{3}{*}{ Variables } & \multicolumn{4}{|c|}{ Rice Farmers } \\
\hline & \multicolumn{2}{|c|}{$\begin{array}{l}\text { With Extension } \\
\text { Contact }(n=77)\end{array}$} & \multicolumn{2}{|c|}{$\begin{array}{l}\text { Without Extension } \\
\text { Contact }(n=49)\end{array}$} \\
\hline & Mean & Std. Dev. & Mean & Std. Dev. \\
\hline Yield $\left(\mathrm{kg} \mathrm{Ha}^{-1}\right)$ & 2105.67 & 153.21 & 1668.39 & 174.68 \\
\hline Seed $\left(\mathrm{kg} \mathrm{Ha}^{-1}\right)$ & 4.4 & 3.20 & 4.0 & 3.40 \\
\hline Fertilizer $\left(\mathrm{kg} \mathrm{Ha}^{-1}\right)$ & 85.6 & 65.06 & 54.0 & 50.20 \\
\hline Labour (manhrs Ha' ${ }^{-1}$ ) & 398.0 & 72.13 & 531.0 & 53.11 \\
\hline Farm size $(\mathrm{Ha})$ & 3.5 & 1.55 & 3.2 & 1.82 \\
\hline Extension contact (dummy) & 1 & 0 & 0 & 0 \\
\hline Age of the farmers & 43.7 & 8.3 & 43.3 & 7.5 \\
\hline $\begin{array}{l}\text { Years of rice production } \\
\text { experience }\end{array}$ & 18 & 4.5 & 19 & 6.7 \\
\hline Years of schooling & 12 & 5.02 & 3 & 2.21 \\
\hline Amount of credit used $(\mathbb{N})$ & 31,500 & 17,850 & 40,600 & 21,200 \\
\hline Years spent in cooperatives & 16 & 2.6 & 8 & 5.4 \\
\hline
\end{tabular}

Source: Field survey, 2010

The estimation of the Cobb-Douglas stochastic production function in Equation 3 concurrently with the technical inefficiency effects in Equation 4 generates the results shown in Table 3. The value of gamma $(\mathrm{Y})=0.771$ is statistically significant at the $1 \%$ level, implying that over $77 \%$ of random variation in rice production is explained by inefficiency. The mean technical efficiency of the pooled sample was $58 \%$. Thus, in a short run, there is a scope for increasing rice production by $42 \%$, by adopting the technology and techniques used by the best farmers.

All the coefficients of the inputs in the production function are positive and statistically significant. The estimated coefficients for fertilizer and seed were significant at $5 \%$ level; while land and labour were significant at $1 \%$ and $10 \%$ levels respectively. The positive coefficients of these variables inputs indicate that increase in quantities of these inputs would result in increase rice output. The summation of the coefficients for all the inputs was 1.056 indicating that the production function assumed increasing returns to scale. Hence, an increase in all inputs by $1 \%$ increases rice yield by more than $1 \%$, ceteris paribus (Table 2). 
Table 3: Maximum likelihood estimates of Cobb-Douglas Stochastic Frontier Production Function (Dependent variable $=$ Natural log of rice output in $\mathbf{k g}$ )

\begin{tabular}{l} 
Variables \\
\hline Stochastic fro \\
Constant \\
In land $\left(X_{1}\right)$ \\
In fertilizer $\left(X_{2}\right)$ \\
In labour $\left(X_{3}\right)$ \\
In seed $\left(X_{4}\right)$
\end{tabular}

\section{Inefficiency model}

Constant

Age of farmer $\left(Z_{1}\right)$

Years of experience $\left(Z_{2}\right)$

Extension contact $\left(Z_{3}\right)$

Years of schooling $\left(Z_{4}\right)$

Amount of credit used $\left(Z_{5}\right)$

Years spent in cooperative $\left(Z_{6}\right)$

\section{Model diagnostics}

Sigma squared

Gamma

Log likelihood function

Mean Technical efficiency
Parameters Coefficient T-value

$\beta_{0} \quad 0.431$

$\beta_{1} \quad 0.361$

$3.742^{*}$

$\beta_{2} \quad 0.216$

$2.718^{*}$

$\beta_{3} \quad 0.157$

$2.124^{\text {** }}$

$\beta_{4}$

0.322

1.781

$1.972^{\star \star}$

Number of observations

$\mathrm{p} \leq 0.05$

$\begin{array}{lll}\delta_{0} & 0.237 & 0.103 \\ \delta_{1} & 0.467 & 1.348 \\ \delta_{2} & -0.555 & -2.036 \\ \delta_{3} & -0.254 & -2.824^{*} \\ \delta_{4} & -0.201 & -2.215^{\star *} \\ \delta_{5} & -0.166 & -1.866 \\ \delta_{6} & -0.193 & -1.930\end{array}$

Source: Field survey, 2010

The result of the inefficiency model in Table 3 shows that all the coefficients of the efficiency variables have negative signs except age of the farmer. As a rule, a negative sign on an estimated parameter implies that the associated variable increases technical efficiency or decreases technical inefficiency, and a positive sign reveals that the reverse is the case. Hence, the coefficients of years of rice production experience, extension contact, years of schooling, amount of credit used and years spent in farmers' cooperatives have negative and significant impact on the production efficiency of the rice farmers.

The coefficient of extension contact is negative and statistically significant at $1 \%$ level, implying that farmers' access to extension services increases rice production efficiency or reduces inefficiency significantly at $1 \%$ level. The result is similar to the findings reported by Obwona (2002) for Uganda and Ratna, et al., (2007) for Nepal.

The technical efficiency distributions of rice farmers with and without extension contact are presented in Table 4. Among the farmers with extension contact, the technical efficiency ranged from 0.21 to 0.94 with a mean of 0.67 . Similarly, technical efficiency among farmers without extension contact ranged from 0.20 to 0.91 with a mean of 0.49 . This implies that there are scopes for increasing rice production by $33 \%$ and $51 \%$ among the farmers with and without extension contact respectively by adopting the technology and techniques used by the best rice farms. Only about $30 \%$ and $10 \%$ of farmers with and without extension contact respectively have exceeded technical efficiency of $69 \%$. 
Table 4: Frequency distribution of technical efficiency estimates for educated and uneducated farmers

\begin{tabular}{lcc}
\hline & \multicolumn{2}{c}{ Rice Farmers } \\
\cline { 2 - 3 } Efficiency Score & With Extension Contact & Without Extension Contact \\
\cline { 2 - 3 } $0.10-0.29$ & $\%$ & $\%$ \\
$0.30-0.49$ & 5.2 & 14.3 \\
$0.50-0.69$ & 18.2 & 44.9 \\
$0.70-0.89$ & 46.8 & 30.6 \\
$\geq 0.90$ & 22.1 & 6.1 \\
Total & 7.7 & 4.1 \\
Maximum TE & $\mathbf{1 0 0}$ & $\mathbf{1 0 0}$ \\
Minimum TE & 0.94 & 0.91 \\
Mean TE & 0.21 & 0.20 \\
Std. Dev. & 0.67 & 0.49 \\
\hline
\end{tabular}

Source: Field survey, 2010

Table 5 shows the production losses due to technical inefficiency of rice farmers with and without extension contact and it was obtained by using equation 2 . The result indicates that the production losses were 1037.13 and $1736.51 \mathrm{~kg} \mathrm{Ha}^{-1}$ among the rice farmers with and without extension contact respectively. This shows that efficient inputs and output combinations are better achieved by more farmers with extension contact, which made them to minimize losses caused by inefficiency.

Table 5: Rice yield loss due to technical inefficiency

\begin{tabular}{lcc}
\hline \multirow{2}{*}{ Variables } & \multicolumn{2}{c}{ Rice Farmers } \\
\cline { 2 - 3 } & With Extension Contact & $\begin{array}{c}\text { Without Extension } \\
\text { Contact }\end{array}$ \\
\hline Mean Technical efficiency & 67 & 49 \\
$(\%)$ & 3142.8 & 3404.9 \\
Frontier yield $\left(\mathrm{kg} \mathrm{Ha}^{-1}\right)$ & 2105.67 & 1668.39 \\
Observed yield $\left(\mathrm{kg} \mathrm{Ha}^{-1}\right)$ & 1037.13 & 1736.51 \\
Yield loss $\left(\mathrm{kg} \mathrm{Ha}^{-1}\right)$ & 49.3 & 104.1 \\
Loss as \% of observed yield & &
\end{tabular}

Source: Field survey, 2010

\section{Conclusion and Policy Implications}

Achieving the goal of complete self sufficiency in rice production through increased farmers' efficiency and productivity depends on the farmers' access to qualitative and effective demand - responsive extension services among other factors. As technically, rice farmers with extension contact are more efficient in minimizing losses and closer to the frontier yield. This justifies more considerations for investment in extension programmes in the current agricultural transformation agenda precisely in agricultural extension transformation agenda (AETA). This would enhance farmers' knowledge, skill and efficiency and accelerate complete substitution of rice imports in the country. Empirically, the results also show that there is ample room for improvement on the level of technical efficiency in rice production in the study area as $60 \%$ of rice growers had technical efficiency score below $70 \%$. 


\section{References}

Aigner, D. J., Lovell, CAK, Schmidt, P. (1977). Formulation and Estimation of Stochastic Frontier Production Function. Journal of Econometrics. 6: 21- 37

Amaza, P.S. and Maurice, D. C. (2005). Identification of factors that influence technical efficiency in rice-based production systems in Nigeria. A paper presented at workshop on policies and strategies for promoting rice production and food security in Sub-Saharan Africa, $7^{\text {th }}-9^{\text {th }}$ November 2005, Cotonou Benin.

Ayinde, O. E., Adewumi, M. O. and Ojehomon, V. E. T. (2009). Determinants of Technical Efficiency and Varietal -Gap of Rice Production in Nigeria: A meta- Frontier Model Approach.A paper presented at the International Association of Agricultural Economics conference, Beijing, China, August 16-22.

Coelli, T. J. (1996). A computer programme for stochastic frontier production and cost function estimation. Department of Economics, University of New England, Armidale, Australia.

Daneji, M. I, Vosanka, I. P. and Undiandeye, U. C. (2010). Agricultural Extension as Catalyst for Food Security in Nigeria: An Overview. Savannah Journal of Agriculture. Bayero University, Kano. Volume 5. Pp 79-85.

Ekeleme, F., Kamara, A.Y., Omoigui, L.O., Tegbaru, A., Mshelia, J., and Onyibe, J.E. (2008). Guide to Rice Production in Borno State, Nigeria. IITA, Ibadan, Nigeria. 20 pp.

Federal Ministry of Agriculture and Rural Development (FMARD) (2012). Commercial Feasibility Study Report for the Establishment of Rice Processing Mills in Nigeria. Accenture, Nigeria, 79pp.

Meeusen, W., and Van Den Broeck, (1977). Efficiency estimation from Cobb-Douglas production functions with composed error. International Economic Review. 18: 435-444.

National Agricultural Extension and Research and Liaison Service (NAERLS) (2010). Agricultural Performance Survey, Kano State.

National Population Commission (NPC) (2006). Human population figures of 2006 census in Nigeria.

Obwona, M. (2002). Determinants of Technical Efficiency amongst small and medium scale farmers in Uganda: A case of tobacco growers. Economic Policy Research Centre (EPRC) Uganda. Occasional paper No. 19. 24pp.

Ogundari K. and Ojo, S. O. (2007). Economic Efficiency of Small Scale Food Crop Production in Nigeria: A Stochastic Frontier Approach. Kamla-Raj Journal of Social Science. 14(2): 123-130

Okoruwa, V.O. and Ogundele, O.O. (2006). "Technical Efficiency Differentials in Rice Production Technologies in Nigeria" Agric Research Paper 134, African Economic Research Consortium, Nairobi.

Ratna, K. J., Laxmi, N. G., Adhrit, P. R., Abhaya, G. and Kamal, R. P. (2007). Impacts of Participatory Extension Program on Technical Efficiency of Farmers in Nepal. Center for Rural Development and Self-help (CRDS). South Asian Network of Economic Institutes (SANEI) Kamalad, Nepal, 28pp 